\title{
Man, Media and Nature in Nigeria: A Critical Collaboration
}

\author{
Dr. Adebayo, Williams Adewumi \& Mrs. Adefunke Anoma ${ }^{1}$
}

\begin{abstract}
Nature and Natural Resources in Nigeria are daily assaulted by anthropogenic forces resulting into extinction while those species still in existence are endangered. Nature is mute in the face of this onslaught, a situation that demands a voice to speak to curtail the aggression. The media as the fourth estate of the realm is no doubt, the voice that is needed at this time because of the pedigree of media in campaigns against anti-social vices and the promotion of democratic virtues. The media in Nigeria, however, has not given due attention to the problems of nature and the effects on humanity, plants, animals and the ecosystems. The objective of this study is to provoke the media into action in order to stem the tide for the present generation and future generations. The challenges of nature in Nigeria are humongous and they include environmental pollution, deforestation, waste management and disposal, desertification, global warming, terrorism and insurgency, flooding, erosion etc. The challenges exist not because there are no laws but basically because of lack of enforcement and information. The study is both doctrinal and empirical while data are obtained from both primary and secondary sources. The study found that the voice of media is potent in mass communication in Nigeria. The study concluded that there is a need for critical collaboration between the media and man for the benefit of nature.
\end{abstract}

Keywords: Nature, natural resources, biodiversity, environmental pollution, desertification etc.

\footnotetext{
${ }^{1}$ Dr. Williams Adewumi Adebayo is a Faculty of Law, Ekiti State University, Ado-Ekiti, Nigeria. Mrs. Adefunke Anoma is Executive Director, Emeraldscape Environmental Development and a Ph.D. Candidate.
} 


\section{Man, Media and Nature in Nigeria: A Critical Collaboration}

\subsection{Introduction}

The earth planet is the habitation of man, plants, animals and other ecosystems. Nature means the physical world in its original unadulterated form including plants, animals, the landscape, and other features and products of the earth, as opposed to humans or human creations. Natural resources mean the natural endowments as opposed to modified resources. The earth planet as designed by the divine is to support man to realize his potentials on the earth planet, however, man in his quest for survival and search for daily needs has assaulted nature to his own detriment. The entire earth environment occupied by man, plants, animals and other natural resources is geographically divided into seven continents and the only one that is not subject to abuse/assault is the Antarctica. Other continents such as Africa, America, Asia, Australia, Oceania, and Europe have been abused and are still being abused by anthropogenic forces causing environmental challenges in our age. In the order of creation, nature is superior to man whereas in the realm of authority, man has a divine mandate to superintend the affairs of the earth and nature. Man, however, in carrying out the divine mandate has impacted nature negatively.

So God created man in his own image, in the image of God created he him, male and female created he them

And God bless them and God said unto them, be fruitful and multiply, and replenish the earth, and subdue it; and have dominion over the fish of the sea and over the fowl of the air, and over every living thing that move upon the earth ${ }^{i}$

Man and nature are designed for a symbiotic relationship. Man depends on nature for survival while at the same time, he is required to support the optimum productivity of nature by tending it. A man is a product of his environment just as the environment is influenced by man. The relationship between man and nature is a variable of the degree of available information. A high level of information will ensure smooth and a hitch-free interaction, while a low level of information may lead to distrust and acrimony. The information required for a very cordial relation between man and nature makes the media imperative in the task of environmental protection for the conservation of nature and natural resources. Man needs information as to the purpose of nature 
and the natural resources deposited on the earth planet. The media is the vehicle of communication between man and nature

And the Lord God took the man, and put him into the Garden of Eden to dress it to keep it ${ }^{i i}$

At the creation of the earth, God as a media practitioner, gave man the assignment to tend the garden and the information needed to succeed.

And the Lord God commanded the man, saying of every tree of the garden, thou mayest freely eat;

But of the tree of knowledge of good and evil, thou shall not eat of it; for in the day thou eatest thereof, thou shall surely die $e^{i i i}$

Man is naturally entitled to the exploitation of nature but it must be done sustainably. The earth environment did not receive adequate attention until 1968 when the United Nations by Resolution 2398(xxiii) of $3^{\text {rd }}$ December, 1968 decided to convene a United Nations Conference on the Human Environment. The proposal that culminated into the resolution was initiated by the government of Sweden through a formalized letter dated 20 May, 1968. At its $23^{\text {rd }}$ session on $3^{\text {rd }}$ December, 1968, the General Assembly adopted Resolution 2398(XXIII) in which it decided to convene the United Nations Conference on Human Environment. The Conference took place in Stockholm, Sweden from $5^{\text {th }}$ to $16^{\text {th }}$ June 1972 and was attended by 113 nations. The Conference adopted a declaration of 26 principles on Human environment. The 1972 Stockholm Conference was followed by another conference in 1992 known as the 1992 United Nations Conference on Environment and Development. The conference took place in Rio de Janeiro, Brazil. The Rio Conference consists of 27 principles for environment and development. The Conference provides that:

States have, in accordance with the Charter of the United Nations and the principles of international law, the sovereign right to exploit their resources pursuant to their own environmental and developmental policies, and the responsibility to ensure that activities within their jurisdiction and control do not cause damage to the environment of other states or of areas beyond the limits of national jurisdiction ${ }^{i v}$. 
Man has exploited the resources of the earth environment to the detriment of the present and future generations, hence the call by the global community for caution in the relationship of man to nature. There is a need to abate the unsustainable practices that are inimical to nature and natural resources. In 1983, the United Nations set up a commission known as the "World Commission on Environment and Development" (WCED) later renamed as the Brundtland Commission. The goal of the Commission was to unite the countries of the world to pursue the goal of sustainable development. The media as the gate keeper for information dissemination occupies a strategic position in the campaign for the conservation of nature and natural resources of the earth environment. The slogan is, if you see something (something awkward affecting the environment), do not hesitate to say something.

A significant development took place before the 1992 Rio Conference and that was the World Charter of Nature of 1982. The General Assembly of the United Nations observed that, Mankind is a part of nature and life depends on the uninterrupted functioning of natural systems which ensure the supply of energy and nutrients ${ }^{v}$

The Conference at its preamble states as follows:

Reaffirming that man must acquire the knowledge to maintain and enhance his ability to use natural resources in a manner which ensures the preservation of the species and ecosystems for the benefit of present and future generations ${ }^{v i}$

The acquisition of knowledge recognized by the Charter is a process that requires the Media to act in the interest of the earth environment and invariably the nature and natural resources. In this task, the media cannot afford to blow muted trumpet. The Charter commands respect for nature while its essential processes are not to be impaired. This provision is at best a paper tiger in mostly the developing nations of the world as the right of nature is violated with impunity while the natural resources are impaired.

The Media cannot afford to be timid in this crusade for the conservation of nature and natural resources, particularly in cementing the relationship between man and the environment. Environmental reporting is not a task that can be done spontaneously, hence this training workshop is to provide media practitioners with some of the hints on the requirements for the task, 
considering the fact that environmental law is a technical field with its own language and enforcement mechanism.

\subsection{Conceptual Framework}

Nature- Black's Law Dictionary, ninth edition at page 1127 defines nature to mean ' a wild condition, untouched by civilization. Something, pure or true as distinguished from something artificial or contrived. In environmental law parlance, this would, therefore mean the natural endowment of the earth planet, be it plants, animals, ecosystems in unadulterated form.

Natural Resources- It is a generic term for the aggregate of natural endowment in the earth environment. The Black's Law Dictionary at page 1127 defines it as 'any material from nature having potential economic value or providing for the sustenance of life, such as timbre, minerals, oil, water, and wildlife.

Conservation- the management of human use of the biosphere so that it may yield the greatest sustainable benefit while maintaining its potential to meet the needs and aspirations of future generations

Biological diversity- means the variability among living organisms from all sources including inter-alia, terrestrial, marine and other aquatic ecosystems and the ecological complexes of which they are part; this includes diversity within species, between species and of ecosystems communities and their non-living environment interacting as a functional unit.

Habitat- means the place or type of site where an organism or population naturally occurs

Genetic resources- means genetic material of actual or potential value

Sustainable use- means the use of components of biological diversity in way and at a rate that does not lead to the long-term decline of biological diversity, thereby maintaining its potential to meet the needs and aspirations of present and future generations. 
Ecoterrorism- is the use or threatened use of violence of a criminal nature against innocent victims or property by environmentally-oriented sub-national groups for environmentalpolitical reasons

Environment- It is the complex of physical, chemical and biological factors/processes which sustain life. It includes water, air, land and all plant and human beings or animal living therein and the interrelationship which exist among these or any of them

Environmental Pollution- is the contamination of the physical and biological processes of the earth/atmosphere system to such an extent that normal environmental processes are adversely affected

Ecosystem- An ecosystem consists of the biological community that occurs in some environment and the physical and chemical factors that make up its non -living or abiotic environment

Pollution- is the introduction of contaminants into the environment which results in harm or discomfort to humans or other living organisms or that can damage the environment

Desert- is defined as a region with so little vegetation that only a limited population (human or animal) can be supported on that land. Deserts may be hot or cold

Desertification- means land degradation in arid, semi-arid and dry sub-humid areas resulting from various factors, including climatic variations and human activities.

Drought- means the naturally occurring phenomenon that exists when precipitation has been significantly below normal recorded levels, causing serious hydrological imbalances that adversely affect land resource production systems

Waste- A substance is a waste if the intention of the person who produced it or who is currently in possession of it is to dispose himself or herself of it

Weather- refers to short -term changes in the atmosphere while climate describes what the weather is like over a long period of time in a specific area. It refers to the average of precipitation, temperature, humidity, sunshine, wind, and other measures of weather that occur over a long period in particular place ( a minimum of thirty years) 
Electronic waste- means discarded electrical or electronic devices

Global warming- refers to the gradual increase in the average temperature of the earth's atmosphere and its oceans

\subsection{Environmental Reporting}

Environmental Reporting refers to the process of disseminating information to the public by media practitioners on developments in the field of environmental study. It is designed to provide useful information that will serve as premises for decision-making and at the same time draw the attention of the society to anthropogenic behaviours that may constitute a hazard to the health of the environment and the habitat.

The general function is to provide information on the state of the earth environment from the troposphere to the exosphere. The troposphere is the most important to man and all living things. It begins from the surface and extends to about seven kilometres. Other layers are the stratosphere, mesosphere, thermosphere and exosphere. The specific functions of environmental reporting are:

(a) Provides information that will aid the government in decision-making on environmental matters

(b) Provides information to the society on the rules and regulations pertaining to certain environmental activities in order to promote social order

(c) Enables the members of the society to know their environmental rights and the mechanisms for seeking redress when such rights are violated

(d) Facilitates professional efficiency by legal practitioners who are involved in the task of advising and counseling clients on environmental issues. Legal practitioners can predict with certainty the consequence of an act resulting into breach of legal provisions

(e) provides foreign investors and exporters information needed in investment decisionmaking in the foreign countries

\section{Validity of Environmental Reporting}

Media practitioners must understand that the information provided on environmental matters are usually taken hook line and sinker as the gospel truth, hence, every caution must be exercised to avoid a situation where the information provided can be regarded as misleading. A piece of 
information that does not represent the correct position of events is nothing more than fake news. The source can be made liable for a misleading information. The following are essential requirements for the validity of environment al reporting:

(a) Relevance- the information must be relevant to the public at a fixed interval

(b) Reliability- The information disseminated must be reliable; otherwise, the media outfit may be ignored by the public or avoided in such a way that it may lose patronage. Reliable Information must be verifiable and free from errors or omissions. It must not be a mere opinion of the reporter

(c) Clarity- language of reporting must be clear and not equivocal or ambiguous. Effective environmental reporting requires the practitioners to have adequate knowledge of the conceptual framework of the subject matter of reporting. A misused of words will make the addressee not to understand the message.

(d) Verifiability- information provided must be such that can be verified and not shrouded in secrecy

(e) Comparability- The information must be such that can be compared between different reporting periods

(f) Objectivity- The media practitioner must be objective and not allow his/her emotion to influence the facts on the issues which are the subject matter of reporting. Personal prejudices or predilections should not be allowed in the reporting

(g) Integrity- The media outfit must be known for integrity, otherwise information from the organization will never be taken serious

\subsection{The Challenges of Nature in Nigeria}

Nature is exposed to and overwhelmed by avalanche of challenges which origin is basically anthropogenic and in few cases natural factors. Nature by divine order is mute, a trait that makes it imperative for the voice of an intermediary. The fourth estate of the realm, that is, the media is the voice that can make vocal the challenges of nature for the attention of the authority. Every day, every time and in every location the anthropogenic assaults on nature are visible whether in the rural settlement or the urban centres. Open defecation in public places is treated as normal in Nigeria especially in the rural villages and in some cases, water bodies are used as public toilets or dumps for disposal of refuse. Environmental pollution, gas flaring, emission of fossil fuels, 
erosion, desertification, bush burning, deforestation, illegal mining operations, overgrazing on land, warfare and insurgency etc., are some of the challenges that have made nature to become endangered and in some cases caused the extinction of the natural resources.

Surveillance of the environment is recognized as one of the main functions of communications in all societies. Information communication technology has aided the process of information dissemination through the use of social media. Social media is a useful channel and it is faster and quicker in exposing unwholesome anthropogenic behaviours that are counter-productive to the health of nature. The media as the gate-keeper is the voice of nature to abate the evil perpetrated ignorantly or deliberated against nature.

The media- electronic, print and social media occupies a strategic position in the education of the society on environmental issues. Nature must be conserved for the present generation and the future generation. It will be callous for the present generation to make the earth environment a liability for the future generation. Nature has a purpose and the lack of knowledge about the essence of nature and the natural endowments is the albatross of nature. Man in his daily quest to satisfy the basic needs of life has interacted with the nature in a hostile manner obviously because of poverty of knowledge. Mass education is required to enlighten the general public of the danger posed to nature by the unconscionable act of man. Life expectancy in Nigeria as at 2020 is about 55 years. Poverty and environmental degradation are among the causes of poor life expectancy in Nigeria. The attitude of man to nature and natural resources is that of a foe, hence the aggressive destruction and assault. In the middle sixties to seventies, one of the things taught to pupils in the primary school s is the respect for nature. This is captured by the poetic lyrics in Yoruba languageYi , yi , ese re si apakan; ma se te kokoro ni; kooro ti iwo ko naani ni, Olorun lo da (Meaning in English, turn, turn your legs, do not trample upon the little creature, the little creature that you do not value is created by God). In Nigeria local honey farmers do not understand the purpose of honey bee beyond that of producing honey. This is the sole reason while honey bee is harvested to destruction. The people should understand that without the honey bee pollinating of flowers, it may be difficult for crops to produce fruit. The earth worm, millipede, centipede, soldier ant, black ant, butter fly etc. exist to support the proper functioning of nature. In Nigeria, valuable trees of medicinal values are destroyed either because of superstition or fell for economic purpose. Palm trees are tapped to destruction by uprooting in order to obtain palm wine. In doing so, other benefits 
derivable from palm trees are sacrificed for the sake of obtaining palm wine. Some trees such as baobab in the centre of the towns have been destroyed because of the beliefs that the trees are the abode of witches.

Wildlife in Nigeria has been poached to extinction while those that are still in existence are endangered because of the destruction of their habitats. Apart from regular hunting for wildlife in Nigeria that has made some wildlife to be in extinction, some wildlife is forced to migrate to other environment that can guarantee their safety. For instance in Nigeria today, apart from game reserves or national parks, eagles cannot be found just like animals such as elephant, lion, tiger, and gorilla. As at about a decade ago, vultures can be found in almost all the villages in Ekiti, but today, vultures are becoming scarce and they can only be found in few states or towns in Nigeria.

In Nigeria, wildlife of flora and fauna which are the sources of raw materials for orthodox and traditional medicine has been depleted or decimated. The forest lands that are the habitats for this wildlife have been converted to estate development, road and rail construction, educational institutions, industries, airports. The forests have lost their aesthetic values and are no longer useful as tourist centre or site for recreation.

Climate change has become a monster to the global community and the developing countries are not excluded from the effects. It is a paradox that despite the feet attained by some countries in the field of science, climate change is still considered a hoax. The media has a role to play in educating the society including the people in government on the reality of climate change. Evidence of climate change dots our landscape through disasters such as flooding, ocean rise, hurricane, and tsunami, tornadoes, shrinking of lakes as well as desertification and drought. Ozone layer depletion and global warming are technical issues that the average man in the society may not understand except through the dissemination of information to the masses. The correlation between acts such as deforestation, gas flaring, emission of green- house gases, atmospheric pollution and the global warming arising from the depletion of ozone layer when explained clearly or dramatized will create a change of attitude in favour of nature. Media can assist in promoting attitude that will support the conservation of nature, afforestation, the use of clean energy, protection of forest lands, modern waste management and disposal system, population control to reduce the pressure on land, modern animal husbandry and grazing system. 
Environmental pollution is another human activity that has detrimental effect not only on nature but also on man. Environmental pollution is the contamination of the physical and biological components of the earth/atmosphere system to such.an extent that normal environmental processes are adversely affected ${ }^{\mathrm{vii}}$. Substances that cause pollution are referred to pollutants and can be biodegradable or non-biodegradable. Biodegradable pollutants are those that can be broken down and processed by living organisms. They constitute temporary nuisance but may pose serious threats if released in large quantities. Non-biodegradable pollutants are the one that cannot be decomposed by living organisms and therefore persist in the atmosphere for long periods. Environmental pollution can manifest through the air, water and soil. The effects of environmental pollution are enormous and disastrous to man, animals, plants and the ecosystem. Diseases affecting the health of human beings such as respiratory, nervous, cardiovascular and skin diseases are traceable to the pollution of the air environment. The pollution of the air environment arising from the use of atomic weapon during the Second World War in 1945 on the two cities of Hiroshima and Nagasaki led to genetic disorder that is still manifest in the genes of the offspring of the survivors till date.

Water pollution can lead to major epidemic outbreak such as cholera, diarrhea, and skin diseases. Apart from the effects on human health, water pollution can lead to the scarcity of drinkable water supply, unemployment, atmospheric destruction, disruption of recreational activities, and obstruction of marine transportation. The effect on marine lives is equally devastating. Oil spills endanger fish hatcheries in coastal water and also contaminate valuable fishes. Water pollution may be caused by vandalisation of pipelines leading to oil spills. It may also results from bunkering, ruptured pipeline, wellheads and flow stations

Agricultural land can be rendered unsuitable for farming by pollution. The United Nations Environment Programme (UNEP) in 2011 released a damning assessment of Ogoniland exposing extensive oil pollution and severe health risks including polluted drinking water. The people have been exposed to barren landscape with abandoned equipment and rusty pipes still oozing oil ${ }^{\text {viii }}$. The oil spills in ogoniland impact vegetation and wildlife such as seabirds. Oil pollution on wetlands such as marshes and mangroves is said to be difficult to remove as the process of removal will create further collateral damage to the soil. Ogoniland oil pollution presents the best example of the effects of pollution across the Niger-Delta area. The role of the media cannot be over- 
emphasised in creating awareness on the danger of pollution to nature. This can be done by the dissemination on the harrowing experience of the society and by reporting the reactions of the people as well as by reporting judicial decisions on the controversy. It should be noted that environmental degradation precipitated the militancy in the Niger-Delta area of Nigeria.

The approach to environmental challenges in Nigeria is curative which is costlier than the recognized environmental standards of preventive and precautionary measures. The Polluter pays principle is a measure to deter prospective polluters as well as imposed sanctions on the polluter. The preventive and the precautionary principles are made pragmatic through the Environmental Impact Assessment Policy. The use of palliative measures through the National Emergency Management Agency are otiose and inadequate to provide succor for the victim of pollution. The media again has a duty in the orientation of the society towards acts that can guarantee a pollution free society.

Environmental reporting is also desirable in the area of waste management and disposal in Nigeria and in all the developing countries of the world. Waste management and disposal in Nigeria is an albatross for nature and the natural endowment on the earth environment. Issue of waste management and disposal is precarious because of the evolution of another complex form of waste which is a product of technological development. E-waste (electrical and electronic waste) is an additional burden for a country like Nigeria still struggling to overcome the problem of local waste substances. The entry of E-waste into the shore of Nigeria and other African countries has made the environment toxic and carcinogenic for human, plants and animals. The Koko toxic waste dump of 1988 in Delta State confirms the evil effect of hazardous wastes .E-waste substances are imported in the name of second-hand products with nearly end of life expiration and without spare parts to repair and maintain when they start malfunctioning. The periodic and regular improvement on the electrical and electronic materials by the manufacturers in the name of model or series renders the substances obsolete. For instance, the black and white television has been rendered obsolete by the colour television. Old vehicle models are phased out without any spare parts to keep them on the road. Carburetor engine has given way to injector engine while petrol engine is gradually giving way to electrical propelled engine. Cell phones are improved daily, hence the need to acquire new models that will meet the needs of the society that is already technologically 
driven. The cross of poverty in Nigeria and the developing countries of the world make the out of use model become the darling of the poor nations.

The lack of consensus between the technologically advanced countries of the west and the poor nations of the south at the negotiation of the 1989 Basel Convention on the Transboundary Movement of Hazardous Wastes and Disposal paved the way for the continuous trans boundary movement of the hazardous wastes into the developing countries. The Basel Convention did not prohibit trans boundary movement of hazardous wastes absolutely despite the demands of the developing nations for outright ban. The technologically developed countries that generate the wastes canvassed the point that they will provide the technology for managing the wastes in the foreign countries to enable them continued to export the wastes. The disagreement on this point created the lacunae on the precise meaning of hazardous wastes in the Convention. It has made it possible for the exporters to export wastes into other countries in the guise of less hazardous wastes. The Basel Convention defines hazardous wastes as substances or objects which are disposed of or are intended to be disposed by the provisions of national laws ${ }^{\mathrm{ix}}$. The implication of this is that what is considered a waste by a nation or an individual may not be a waste to the other. In Kent County Council v Queensborough Mill Coy Ltd ${ }^{x}$, the defendant company was charged with depositing waste on land without a disposal license contrary to the law. The material consisted of ballast, China clay and broken pottery from a disused site cleared by a demolition company. The material was later used to fill an area subject to subsidence. The Magistrate Court decided that such material was not a waste as it was used for the purposes of filling. On appeal to the Divisional court, the court held that though the material was put to a useful purpose, that was not a relevant factor in deciding whether the material was a waste or not. The important factor was the nature of the material when it was discarded. The effect of the decision is that as a general rule, a material will be a waste if the intention of the person who produced the material or who is currently in possession is to rid him or her of it. Wastes can be classified as solid wastes, liquid wastes, radioactive wastes, electronic wastes and clinical wastes. The various classes of wastes if not properly disposed or managed can affect nature and natural resources of the earth environment.

In Nigeria, the greatest challenge of waste is the problem of disposal and management. The dumping of refuse on water channels has the effect of obstructing the free flow of water and the destruction of aquatic life. In the rural villages, open defecation in public places is considered 
normal, hence it is not uncommon to see people defecating on rocks, mountains, water bodies or channels. In the cities, there are houses built without toilet facilities despite the existence of town planning authorities' supervision and monitoring. The sanitation departments are only seen during the monthly environmental sanitation to ensure compliance with the order of restriction of movement in the three-hour period of 7a.m to 10a.m. The dumpsites in the different locations are the habitat for mosquitoes, rats, vermin, reptiles and other dangerous creatures.

The media as the intermediary and the gate-keeper for information dissemination has a crucial role to play in the proper management and disposal of wastes. Social sanction by exposure of culprits will perform magic in curtailing indiscriminate disposal of wastes. Nylon wastes, water bottles, cans for beverages, wrappers are easily dispersed from one location to the other. To ensure a healthy environment that will guarantee the sustainability of nature, there will be a need to reconsider the $\mathbf{1 9 8 4}$ War against Indiscipline policy of Buhari/Idiagbon regime at all levels of the social life. Media campaign will ensure that everybody participates to ensure healthy relationship between man and nature.

Nigeria is blessed with abundant Forest lands across the different states especially in the southern part. The forest lands have become haven for criminals perpetrating heinous crimes such as kidnapping, banditry, cultivation of narcotic drug, illegal mining. Forests are the home of biodiversity of the wild fauna and flora which unfortunately are gradually decimated through illegal operations. The major forests in Nigeria includes the Ise-Ekiti forest, Oluwa forest reserve, Okomu forest reserve, Omo forest reserve, Okeluse forest reserve, Oba hills forest reserve, Idanre forest reserve, Edumanon forest reserve, Afi forest reserve, and Akure forest reserve. The Forest Reserves in the southern part of Nigeria otherwise known as rain forests are blessed with adequate timbre resources as well as wild fauna and flora unlike the savannah regions in the northern part of Nigeria which are not richly endowed with timbre resources and wildlife and plants.

The control, management and creation of forest reserves are issues exclusively vested in the government of each state of the federation. Forestry law defines forest to include government forest reserves, protected forests, local government forest reserves and communal forests ${ }^{\mathrm{xi}}$. The government- owned forest reserves as gazetted are managed by the Forestry department with experienced professionals and technical staff. Some forests not under the control and management of the state government are known as free areas but exploitation of trees from these areas is subject 
to the grant of permission by the government. There are also conservation areas such as National parks, Game reserves and wildlife sanctuaries. National parks in Nigeria include Kainji parks, old Oyo parks, Cross River parks, Chad basin parks and Gashala parks.

Game Reserves in Nigeria include Yankari, Akwa, Falgore, Kwale,Sambisa, Okomu, Ologbo etc. The power to constitute a land as forest reserves is vested in the government who may constitute as government forest reserves or local government forest reserves:

(a) Lands at the disposal of government

(b) Any communal or other lands in respect of which it appears the Governor on the advice of the Chief Conservator of Forests that the forest growth on such lands be protected or reserved, or forest growth be established ${ }^{\mathrm{xii}}$.

Any native, and the chief or head of any native community on behalf of such community, notwithstanding any native law or custom to the contrary shall be entitled to enter into agreement to grant and convey absolutely to the government any land, any right in and over any land proposed to constitute a forest reserve. The power extends to the grant of any licence or permit for the taking of forest produce owned by him or them ${ }^{x i i i}$. If any right within a government forest reserve is not exercised for a period of ten years, such right shall be deemed to be extinguished. This is the provision that the sponsors of banditry and kidnapping are misinterpreting for their trespass on the forest reserves in the southern part of Nigeria. The media has a role to enlighten the masses on the unfettered right of the communities and the government on the forest lands in the state. Illegal occupants are to be treated as criminals under the criminal laws. Ekiti Sate law of Forestry prohibits the following activities ${ }^{\mathrm{xiv}}$.:

(a) Taking of forest produce

(b) Uprooting, burning, stripping of the barks or leaves or otherwise damages to any tree

(c) Setting fire to any grass or herbage; or kindles a fire without taking due precaution

(d) Smokes or light fire

(e) Pasturing cattle or permitting cattle to trespass

(f) Digging, cutting or cultivating the soil or making a farm plantation 
(g) Trespassing in any part of forest where trespass is prohibited

(h) Constructing any dam or weir across any river or strea

(i) Resides or erecting any building

(j) Hunting or fishing

(k) Damaging or destroying forestry property

It is an offence in Ekiti State for any person to cut, burn, destroy, or injure any tree which has been planted on the side of any road or path except with the consent of the Forestry officer ${ }^{\mathrm{xv}}$. The prohibited acts with regards to the Forest lands are perpetrated on daily basis without any serious attempt to apprehend the criminals. The media has a role to play in drawing the attention of the government to the danger posed to our forests by the invasion of aliens who have nothing to lose other than to endanger our nature and natural resources. The Forest lands should be secured with trained Forest Guards licensed to carry ammunitions. The security network created by the government should equally be drafted into the forests to complement the work of the Guards. Again, officers of the Western Nigeria Security Network (WNSN) should be authorized to carry sophisticated weapon such as the AK-47 if they are to effectively secure the forests

Protection of nature and natural resources is not limited to forest lands owned by the government or communities but it extends also to privately owned farmland. In Ekiti State, the law provides that where plants, seeds, soil, containers, straw or other materials or any other similar goods or things are found, or suspected to be infected with any plant disease or pest, the government is empowered to order the destruction ${ }^{\mathrm{xvi}}$. Owners of oil palm or coconut palm which is attacked by bud-rot is required by law to cut down the tree and destroy same by fire ${ }^{\text {xvii }}$.Cabbage tapping is prohibited in Ekiti State ${ }^{\text {xviii }}$. Cabbage tapping is the process of cutting away palm tree below the growing point before tapping. Government is empowered to enter any cocoa farm and marks any tree with swollen shoot disease for destruction ${ }^{\mathrm{xix}}$.

Media role in conservation of nature can only be effective where the media practitioners are not stranger to the subject matter. The media practitioners apart from understanding the language of the field must have an elementary knowledge of the laws and regulations in the field. Media practitioners should also be familiar with judicial pronouncements on the dispute in environmental issues. Acquisition of knowledge for the performance of this role is the essence of regular training 
.Media practitioners should also not limit the acquisition of knowledge to the local environment. They are also required to be familiar with developments in the international circle on environmental issue. Conventions, Protocols and agreements are the primary source from where Media practitioners can depend on as premises to buttress their legal discourse in media communication. Media practitioner should also be familiar with the enforcement mechanisms of environmental law such as inspection, search, prosecution, arrest, seizure, detention etc. to be able to draw conclusion and form a valid opinion

\subsection{Aspects of Critical Collaboration Required from the Media}

The Media in Nigeria is critical to the task of the task of conservation of nature and natural resources. The assaults that have threatened the existence of nature and natural resources are the products of ignorance and lack of information on the essence of nature. The media is needed to promote a paradigm shift from the acts or omissions inimical to the conservation of nature to a friendly attitude that will guarantee the existence of nature and the natural endowments. Man is entitled to live just as nature and natural resources are entitled to exist. Man in his quest for the basic needs of life- food, clothing and shelter depends on nature, but that is not an excuse to exploit the natural endowment to extinction. There is obligation imposed upon man to ensure the existence of nature for the future generations. There is a need for information on the modern methods of exploitation that will not threatened the existence of nature and the natural resources. Man is both creature and moulders of his environment. The natural growth in population in developing countries of the world and particularly, Nigeria continuously presents problems for the conservation of nature and natural resources. There is a need for a departure from the habits of man that endanger nature and natural resources. This is the truth, hence the United Nations at the 1972 Stockholm Conference on Human Environment observed that,

the natural resources of the earth, including the air, water, land, flora and fauna and especially representative samples of natural ecosystems, must be safeguarded for the benefit of present and future generations through careful planning or management, as appropriate $^{x x}$.

The Conference similarly observed that 
Man has a special responsibility to safeguard and wisely manage the heritage of wildlife and its habitat, which are now gravely imperiled by a combination of adverse factors. Nature conservation, including wildlife, must therefore receive importance in planning for economic development $t^{x x i}$.

Nature and the natural endowment must be exploited in ways that will not threaten their survival or existence. In the Niger Delta area, fishermen are to imbibe more decent ways of fishing in accordance with the laws and regulations. It is illegal to take or harm fishes within Nigerian waters by use of explosives, poisonous or noxious substances ${ }^{x x i}$. The punishment for violating this provision on conviction of the offender is a fine of Fifty Thousand Naira or imprisonment for a period of two years. Unauthorised operations of motor fishing boats within the inland waters of Nigeria is a crime ${ }^{x x i i i}$ just as the taking or destruction of fish by harmful means is an offence punishable with a fine or an imprisonment term of two years or both ${ }^{\text {xxiv }}$. Hunting for wildlife in Nigeria is taking as a vocation, hence along the highways, wildlife are displayed for sale after hunting them with traps or bullets. In some cases, wildlife habitats are invaded and wildlife smoked to death. In Nigeria, some social occasions such as weddings, burial, graduation, child naming ceremonies, house warming, conferment of chieftaincy titles, as well as some religious activities are not deemed properly performed in the absence of the wildlife meat. A change of attitude needed is to enforce the law against wildlife hunting. Any person who desires the meat of wildlife should go into wildlife breeding. Another area where there is a need for change of attitude is the area of illegal felling of trees such as palm trees and timbres. Timbre is required for construction purposes but for every tree fell, another must be replanted. In Nigeria, palm wine is a liquour consumed by both old and young, however, the process of tapping the juice is another area that is detrimental to nature. Palm wine can be obtained by either climbing the palm tree (a common practice in the Southeast) whereas in the southwest area, palm trees are occasionally uprooted for the purpose of tapping palm wine. Uprooting of palm trees render the vegetation around and the soil to intensive heat that can lead to desertification or drought. Farming is the major occupation of the rural dwellers in Nigeria. There is a need for a departure from unwholesome practices such as bush burning, uprooting of trees and the use of chemical fertilizers in farming. At the beginning of every planting season, farmers usually clear the land and uproot trees which are later set ablaze. These practices are harmful to nature and the natural resources. 
The media is needed in Nigeria to ensure enforcement and compliance with the local statutes, treaties, conventions and protocols for the protection of the environment. Nature and natural resources in Nigeria have adequate legal instruments that can be deployed for their conservation, however, the government either at the federal, state or local levels lacks the political will to enforce such laws. For instance in Nigeria, the forest lands have become the den of criminal despite the arrays of legal provisions that prohibit trespass or illegal operations. The voice of the media is needed to provoke action by the government. It is required that the various forests should be manned by Forest Guards but such category of civil servants are very few as they are either not employed while there are no provisions to train people to take over from those that have retired. Apart from inadequate personnel to man the forests, those Guards still in service are not provided with ammunitions and other equipment to perform in the face of banditry, kidnapping and narcotic drug farmers.

The ruling class in Nigeria requires more information about the level of poverty that exists among the masses. The media should draw the attention of the government to measures that can foster the desired change of orientation in Nigeria. The anthropogenic factors affecting nature and the natural endowment are traceable to poverty and poor state or complete lack of social infrastructure. In Nigeria, a large percentage of the rural dwellers depend on firewood for cooking, hence trees are fell on daily basis. In the towns and cities bakery firms rely on firewood for bakery. The class considered as average in the society still depends on kerosene stove for cooking but the cost is also unbearable while cooking gas is only for the wealthy class. The epileptic nature of electricity in some fortunate towns and cities connected with electricity makes the average man who wants to survive to engage in acts inimical to nature.

Another critical area for collaboration by the media is the area of reporting of judicial decisions on environmental dispute. Environmental reporting in the field of environmental disputes will enable the individual and communities that are victims of degradation to seek relief against the aggressor. In Nigeria, the Niger-Delta region is mostly affected by degradation arising from the operations of Oil Companies. The water resources are polluted frequently, a situation that makes it difficult for the people in the areas to have drinkable water supply. The inhabitants of some of the areas, especially the coastal settlement depend on rainwater harvested during the rainy season of the year. Air pollution occurs from gas flaring despite the existence of the Gas Flaring Act which requires 
the Oil companies to re-inject associated gas. The people of Ogale and Bille communities in the Niger-Delta Area that suffered from oil pollution of their communities by the activities of Royal Dutch Shell recently instituted an action against the company. Though, Shell did not dispute that its activities caused the pollution but contended that Royal Dutch Shell plc, could not be legally responsible for the harm caused to the communities and therefore requested that the cases should not be heard in England. The Supreme Court in a landmark judgment held that the case can be heard in England ${ }^{\mathrm{xxv}}$. The judgment handed over by the Supreme Court in the United Kingdom will encourage other individuals or communities to seek legal redress.

The 1992 United Nations Conference on Environment and Development in Rio de Janeiro, Brazil identified a critical area of collaboration that can foster the cordial relationship between man and nature and that is the area of decision -making. The Conference in its declaration observed as follows:

Environmental issues are best handled with the participation of all concerned citizens, at the relevant level. At the national level, each individual shall have appropriate access to information concerning the environment that is held by public authorities, including information on hazardous materials and activities in their communities, and the opportunity to participate in decision-making processes. States shall facilitate and encourage public awareness and participation by making information widely available. Effective access to judicial and administrative proceedings, including redress and remedy, shall be provided ${ }^{x x v i}$

The Media should educate the masses about their rights to participate in every decision-making on the environment. The government should also know that it is by the participation of the masses that the nature and natural resources can be adequately protected as the masses would have a sense of belonging. The declaration provides also that indigenous people and their communities, and other local communities have a vital role in environmental management and development because of their knowledge and traditional practices. States should recognize and duly support their identity, culture and interests and enable their effective participation in the achievement of sustainable development ${ }^{\mathrm{xx} \text { ii }}$ 


\section{Summary, Conclusion and Recommendations}

In Nigeria, nature and natural resources are not exempted from the challenge of insecurity that has plagued Nigeria like leprosy from 2009. Nature and natural resources in Nigeria for over a century have been exposed to all forms of insecurity that have threatened their sustainability ever before the recent scourge to human existence from 2009 by kidnappers, bandits, terrorists, insurgents and ritual killers. It is ironical and paradoxical that the assault on nature and natural resources are mainly anthropogenic and from the ultimate beneficiaries of nature and natural resources. The study observes that despite the arrays of legal frameworks, both domestic and international, nature is assaulted and natural resources are daily decimated and aggressively endangered. Nature is mute in the face of assault. The study has revealed that the relationship between man and nature with the natural resources cannot be reordered with the use of law as an instrument of social engineering. The change of attitude towards nature must be inculcated through the dissemination of information. The media is critical and imperative in the task of achieving harmonious relationship while exercising the sovereign right to exploit natural resources. The goal of sustainable development will remain a mirage in Nigeria and the developing countries unless the media takes the bull by the horn and champion the cause for the cause for the conservation of nature and natural resources. Nature and natural resources belong to the realm of environmental studies dotted with galaxies of legislation globally, however, the legal instruments are nothing more than paper tiger for lack of enforcement and awareness. The law for conservation of nature and natural resources in Nigeria must according to

Pound ${ }^{\text {xxvii }}$ build as efficient a structure of society as possible which requires the satisfaction of the maximum of wants with the minimum of friction and waste. The law must promote social and public interest above individual interest. The critical collaboration required is for the media to perform a dual role of enlightening the masses and at the same time point out to the legislature the quality of law needed for the conservation of nature and natural resources in Nigeria. It has also been observed that issues affecting the environment and particularly nature are usually not given adequate coverage by the media while reporting. This is so because the media practitioners are also not sufficiently informed. Media organisations should embark on regular training to equip their officials with environmental education while at the same time partner with non-governmental 
organisations involved in environmental issues. This will enable the media to be acquainted with developments in environmental studies.

The Media is indispensable in the relationship between man and Nature if the goal of sustainable development is to be a reality. The anthropogenic causes of assault on nature are purely because of lack of knowledge. Information when made available to the right group of people at the right time by the right people through the right channel will go a long way in stemming the hostility towards nature. Training programmes should be made available to Media practitioners on environmental issues by activist in environmental field as well as the government. Government at both the federal and state levels should at regular intervals sponsored programmes on the environment if they are actually interested in conserving nature and natural resources.

\section{References}

'. Genesis 1:22 \& 28 of the Holy Bible

ii. Genesis $2: 15$

iii.Gen. $2: 16 \& 17$

iv . Principle 2 of the Rio Declaration on Environment and Development

v. See the Preamble to the Charter

vi . ibid

vii .Adebayo, W.A (2018) Contemporary Issues in International Environmental Law' Ado-Ekiti :Eksu Press, p.31

viii Friends of the Earth International, A Journey through the Oil spills of Ogoniland , Retrieved March 6,2021 from .www.foei.org>news>oil -spills-og

ix . Article 2(1) of the 1989 Basel Convention

x . (1980) 89 LGR 306

xi . Cap F3 Ekiti State Forestry Law, 2012

xii . S.6 of the Forestry Law, Ekiti State

xiii . S.20 of Forestry Law

xiv .S. 19

${ }^{\mathrm{xv}}$..S.6 Forestry Regulation of the Forestry Law

${ }^{x v i}$.S.8 Agriculture Law Cap 4, Ekiti State 
xvii . S.3 Agriculture Law Subsidiary legislation

xviii . S.4 Regulations of the Agriculture Law

xix . Sections $3 \& 4$ Swollen Shoot Regulations of Agriculture Law

xx . Principle 2 of the 1972 UN Conference on Human Environment

xxi . Ibid, Principle 4

xxii .Sea Fisheries Act, Cap S4, LFN 2004

xxiii . S.1 Inland Fisheries Act, Cap I10, LFN 2004

xxiv . Ibid, S.10

${ }^{x x v}$ Sandra Laville and Emmanuel Akinwotu,.' Nigerians can bring claims against Shell in UK, Supreme Court rules' Retrieved from The Guardian. theguardian.com <accessed 3/03/2021> xxvi .Principle 10 of the 1992 United Nations Conference on Environment and Development, Rio xxvii .Ibid, Principle 22

Xxviii.Doherty, M (2004) Jurisprudence: The Philosophy of Law, London, Old Bailey Press. P.189 